\title{
AKUNTABILITAS SEKTOR PUBLIK KOMISI PEMILIHAN UMUM PROPINSI BALI TAHUN 2018
}

\author{
I Putu Dharmanu Yudartha ${ }^{1}$, Piers Andreas Noak ${ }^{2}$ \\ ${ }^{1}$ Program Studi Ilmu Administrasi Negara, Fakultas Ilmu Sosial dan Ilmu Politik, \\ Universitas Udayana Bali. \\ ${ }^{2}$ Program Studi Ilmu Politik, Fakultas Ilmu Sosial dan Ilmu Politik, \\ Universitas Udayana Bali. \\ E-mail:p_dharmanu@unud.ac.id
}

\begin{abstract}
Abstrak
Kinerja Komisi Pemilihan Umum Provinsi Bali perlu dilakukan evaluasi terutama dari segi akuntabilitas terkait pengelolaan keuangan. Dana Hibah yang diberikan kepada Komisi Pemilihan Umum Provinsi Bali dalam pemilihan Gubernur dan Wakil Gubernur Bali tahun 2018 perlu dilakukan analisis. Proses penganggaran dan penggunaan anggaaran terkait pemilihan Gubernur dan Wakil Gubernur Bali terjadi dinamika dalam konteks politik anggaran. Hal tersebut yang menjadi dasar dalam penelitian ini untuk dilakukan analisa. Adapun metode yang dipakai adalah metode kualitatif dengan pendekatan deskriptif. Hasil penelitian menunjukkan bahwa akuntabilitas secara hukum, proses dan perencanaan pada Komisi Pemilihan Umum Provinsi Bali telah sejalan dengan peraturan yang berlaku. Sedangkan, aspek akuntabilitas kebijakan menunjukkan bahwa secara efisiensi dalam mencapai tujuan sudah tercapai. Akan tetapi, efektivitas kebijakan atau program pemilihan Gubernur dan wakil Gubernur Bali belum berjalan maksimal karena peningkatan jumlah suara tidak sah.
\end{abstract}

Kata Kunci : Akuntabilitas, Komisi Pemilihan Umum, Provinsi Bali.

\section{Public Sector Accountability for Bali Provincial Electoral Commission in Year 2018}

\begin{abstract}
The performance of the Bali provincial Elections Commission (KPU) needs to be evaluated especially in terms of accountability in relation to financial management. The grants awarded to the Bali provincial Electoral Commission (KPU) in the election of governor and deputy Governor of Bali in 2018 needs to be analyzed. The process of budgeting and the usage regarding the election of governors and the Bali deputy Governor occurs dynamics in the context of the political budget. It is the basis for analysis. This study used qualitative method with a descriptive approach. The results showed that the legal accountability, process and planning of the Bali provincial Electoral commission was in line with the prevailing regulations. Meanwhile, the accountability aspect of the policy shows that efficiencies in achieving the objectives are achieved. However, the effectiveness of the governor's policy or election program and the deputy governor of Bali have not walked the maximum due to an increase in the number of unauthorized votes.
\end{abstract}

Keywords: accountability, election Commission, Bali province.

\section{PENDAHULUAN}

Kinerja Komisi Pemilihan Umum pada setiap pemilu umum menjadi sorotan publik terkait dari sisi akuntabilitas. Akuntabilitas ditujukan untuk memperoleh jawaban atas pertanyaan berhubungan dengan kinerja pelayanan dalam pendataan, 
verifikasi dan kelayakan calon pemimpin (presiden hingga kepada daerah) untuk dipilih oleh pemilih yang terdaftar (masyarakat). Akuntabilitas yang dimaksud lebih berorientasi pada sektor publik. Publik yang dimaksud adalah tentunya pemerintah pusat dan daerah, masyarakat dan stakeholder penyelenggaran pemilu misalnya partai politik. Komisi Pemeilihan Umum harus mampu mempertangungjawabkan kinerja serta capaian kinerja untuk membuktikan kepada publik. Akuntabilitas sektor publik, saat ini lebih berorientasi terhadap capaian kinerja yaitu outcome kinerja yang telah dirancang sebelumnya, tidak lagi hanya berorientasi pada proses sebagai bentuk kinerja.

Agenda kerja Komisi Pemilihan Umum tahun 2018-2019 di tingkat pusat sampai daerah menjadi sangat padat karena merupakan tahun politik. Tahun 2018 merupakan pelaksanaan pemilu kepada daerah secara serentak dan tahun 2019 merupakan pemilihan legislatif dan eksekutif (Presiden-wakil presiden). Provinsi Bali tentunya termasuk dalam agenda tersebut khususnya pada pemilihan kepada daerah di tingkat kabupaten yaitu Kabupaten Klungkung dan Kabupaten Gianyar serta Pemilihan Gubernur dan Wakil Gubernur Bali. Walaupun kegiatan tersebut telah berlangsung dan telah menghasilkan pemimpin sesuai dengan keinginan rakyat Bali, tentunya perlu dilakukan evaluasi kinerja Komisi Pemilihan Umum Provinsi Bali dalam melaksanakan agenda kerja tersebut.

Pelaksanaan Pemilihan Kepala Daerah serentak di Bali pada tahun 2018 merupakan domain Komisi Pemilihan Umum Provinsi Bali akan tetapi perlu sinergitas dengan pemerintah daerah Provinsi Bali dalam pelaksanaannya terutama berkaitan bantuan keuangan melalui dana Hibah uang. Permasalahan yang dihadapi Komisi Pemilihan Umum Provinsi Bali adalah ketidak sesuaian anggaran yang diterima dengan rencana anggaran yang diajukan dalam pemilihan Gubernur dan wakil Gubernur Bali tahun 2018. Secara teknis proses pengajuan kebutuhan anggaran yang dilakukan Komisi Pemilihan Umum Provinsi Bali adalah sebagai berikut :

a. Proposal Rencana Kebutuhan Anggaran Pelaksanakaan Pemilihan Gubernur dan Wakil Gubernur Bali Tahun 2018 pertama kali disampaikan ke Pemerintah Daerah Provinsi Bali tanggal 17 Maret 2016 dengan Usulan sebesar Rp.268.635.895.529;

b. Pembahasan kedua, dilaksanakan di Ruang Rapat Kantor Gubernur Bali yang dipimpin langsung oleh Sekretaris Daerah Provinsi Bali selaku Ketua TAPD Provinsi Bali, pada pembahasan kedua, KPU Provinsi Bali menyampaikan kebutuhan anggaran sebesar Rp. 254.379.000.000 karena ada perubahan regulasi dan aturan perundang-undangan terkait penyelenggaraan pemilihan.

c. Pembahasan ketiga dilaksanakan pada tanggal 15 -17 Mei 2017 bertempat di Ruang Rapat Kantor Bappeda Litbang, KPU Provinsi Bali melakukan pemotongan RKB sebesar Rp.25.018.497.300 dengan melakukan pengurangan di beberapa kegiatan, yaitu:

1) Kegiatan Sosialisasi;

2) Kegiatan Kampanye;

3) Biaya Distribusi Logistik; 
4) Pengadaan Alat Peraga Kampanye (APK);

5) Bimbingan Teknis Badan Adhoc;

d. Dengan melakukan pengurangan beberapa kebutuhan biaya tersebut mengingat TAPD menyampaikan bahwa APBD Provinsi Bali sedang mengalami depisit Pendapatan Anggaran Daerah, oleh karena itu RKB yang semula diusulkan sebesar Rp. 254.379.000.000 menjadi Rp.229.360.000.000.

Berdasarkan uraian diatas, memperlihatkan bahwa terjadi pengurangan kegiatan atau tahapan karena realisasi anggaran tidak sesuai dengan rencana kebutuhan anggaran yang diajukan. Hal tersebut tentunya berpotensi mempengaruhi proses pemilihan gubernur dan wakil gubernur di Bali. Adapun dalam Penelitian tentang Akuntabilitas Pengelolaan Anggaran tahun 2018 di Komisi Pemilhan Umum Provinsi Bali adalah sebagai berikut:

1. Memperoleh informasi terkait perubahan serta yang mendasari relisasi anggaran dalam pemilihan Gubernur dan Wakil Gubernur Provinsi Bali Tahun 2018;

2. Akuntabilitas (Pertanggungjawaban) atas pengelolaan keuangan terhadap stakeholders, dalam hal ini bagaimana pengelola keuangan dapat bertanggung jawab secara Hukum, Proses, perencanaan dan kebijakan.

\section{METODE PENELITIAN}

Metode penelitian yang digunakan dalam penelitian ini adalah penelitian kualitatif, dengan pendekatan deskriptif. Peneliti melakukan analisis secara mendalam dan komprehensif terkait obyek penelitian serta data-data pendukungnya. Sugiyono (2016:24) penelitian kualitatif dapat diartikan sebagai metode penelitian yang berlandaskan pada filsafat postpositivisme, digunakan untuk meneliti pada kondisi objek yang alamiah, (sebagai lawannya eksperimen) dimana peneliti sebagai instrumen kunci, teknik pengumpulan data dilakukan secara triangulasi (gabungan), analisis data bersifat induktif/kualitatif, dan hasil penelitian lebih menekankan dari pada generalisasi. Fokus penelitian ini adalah akuntabilitas sektor publik dilingkup Komisi Pemilihan Umum Provinsi Bali.

\section{HASIL DAN PEMBAHASAN}

Kinerja Komisi Pemilihan Umum pada setiap pemilu menjadi sorotan publik terlebih dari sisi akuntabiltas, dalam birokrasi pemerintahan akuntabilitas mengalami perubahan yang signifikan didasari oleh perkembangan paradigma dari pemerintahan itu sendiri, adapun dasar hukum yang tertuang dalam proses, perencanaan, dan kebijakan pada KPU Provinsi Bali terutama hibah daerah Permendari 32 tahun 2011 menyebutkan pemerintah daerah dapat memberikan hibah sesuai dengan kemampuan daerah, yang mampu memprioritaskan pemenuhan belanja urusan wajib, yang mampu menunjang sasaran program kegiatan pemerintah daerah. Pengelolaan hibah tidak hanya didasari oleh Permendagri No 32 Tahun 2011 akan tetapi diperkuat dengan Pemendagri nomor 14 tahun 2016 dan Permendagri Nomor 18 tahun 2017 (hasil wawancara, 2018) 
Ketentuan pengelolaan hibah terhadap pemerintahan daerah akan dilakukan seleksi, berdasarkan hasil seleksi, kementerian teknis mengajukan usulan terkait besaran hibah dan daftar penerima hibah, penyaluran dana hibah dilakukan melalui mekanisme pemindah-bukuaan dari RKUN ke RKUD berdasarkan permintaan dari kepala daerah, kegiatan beserta rencana kebutuhan anggaran atau rencana anggaran biaya, serta kelengkapan administrasi, pengajuan dana hibah dari masyarakat ditujukan kepada gubernur Bali yang akan masuk ke biro hukum untuk didistribusikan sesuai OPD terkait dengan bidangnya, maka melalui OPD akan mengecek factual atau melakukan observasi dilapangan ketentuan-ketentuan berdasarkan peraturan perundang-undangan yang dapat menjadi pedoman dalam memberikan pembatasanpembatasan yang jelas dan tegas untuk pemberian bantuan hibah berbentuk uang yang bersumber dari APBD oleh pemerintah daerah agar permasalahan-permasalahan hukum sebagai akibat penyalahgunaan pemberian bantuan hibah mampu diminimalisasi serta ditiadakannya.

Bantuan hibah dapat tersalurkan dengan tepat waktu dan tepat sasaran. dalam penerapan akuntabilitas, maka bagaimana pengelolaan pemerintah pada penyusunan dan pelaksanaan APBD pemerintah yang akan menjadi sorotan utama karena APBD adalah instrumen terpenting dalam suatu pemerintahan. APBD atau Anggaran Pendapatan Belanja Daerah ialah rencana keuangan tahunan pemerintah daerah di Indonesia yang disetujui oleh Dewan Perwakilan Rakyat Daerah. APBD ditetapkan dengan Peraturan Daerah. Salah satu jenis belanja daerah yang telah tercantum dan teranggarkan di APBD yaitu adalah dana bantuan sosial (bansos) dan dana hibah.

Perbandingan hibah dan Bansos terletak pada tujuannya jika hibah bersifat tidak wajib dan tidak mengikat serta tidak terus menerus, maka Bansos bertujuan untuk melindungi dari kemungkinan terjadinya resiko sosial. Pemerintah daerah dapat memberikan bantuan sosial kepada individu, keluarga, dan masyarakat yang mengalami keadaan yang tidak stabil sebagai akibat dari krisis sosial, ekonomi, politik, bencana atau fenomena alam agar dapat memenuhi kebutuhan hidup.

Transparansi atau keterbukaan tidak akan terwujud jika dalam pelaksanaannya belum adanya kerangka hukum yang jelas rule of law. Dalam penyusunan anggaran Pilkada, KPU menggunakan Permendagri 14 Tahun 2016, serta permendagri 18 tahun 2017 tentang Pengelolaan keuangan daerah yang menyatakan Pemberian hibah sebagaimana dimaksud pada ayat (1) ditujukan untuk menunjang pencapaian sasaran program dan kegiatan pemerintah daerah sesuai urgensi dan kepentingan daerah dalam mendukung terselenggaranya fungsi pemerintahan, pembangunan dan kemasyarakatan dengan memperhatikan asas keadilan, kepatutan, rasionalitas, dan manfaat untuk masyarakat.

Perubahan anggaran terkait dana hibah sebenarnya disebut stimulant dalam pelaksanaan kegiatan dan tidak dapat dibantu, OPD terkait akan memberikan rekomendasi ke Gubernur serta Bappeda, dari rekomendasi maka Bappeda mencantum dalam perencanaan anggaran, lalu BPKAD membawa kepada anggota DPRD. Selanjutkan APBD pada lambiran ketoga akan kehilangan. Calon penerima hibah tidak dilibatkan secara langsung. 
Kerangka hukum yang jelas rule of law adalah modal awal transparannya suatu anggaran. Penyusunan anggaran pilkada disusun melalui dua tahap. Tahap pertama disusun dan dirapatkan bersama internal KPU perubahan anggaran terkait dana hibah harus benar efektif dan efisien serta sesuai dengan aturan yang ada. Setelah anggaran disusun oleh internal KPU, maka anggaran tersebut akan diserahkan atau diajukan kepada Pemerintah dalam bentuk proposal. Pada tahap kedua, anggaran yang telah disusun oleh KPU akan dibahas bersama dengan Tim Anggaran Pemerintah Daerah (TAPD) bersama dengan Bagian Anggaran (Banggar) DPRD. Pada tahap kedualah anggaran tersebut akan dibahas kembali, jika anggaran telah dianggap sesuai maka anggaran tersebut akan disetujui. Perubahan anggaran terkait dana hibah sebagai stimulant dalam pelaksanaan kegiatan sehingga tidak dapat dibantu sepenuhnya, OPD yang terkait akan memberikan rekomendasi kepada gubernur Bali melalui Bappeda, dari rekomendasi maka Bappeda akan mencantumkan dalam perencanaan anggaran, kemudian BPKAD membawa data kepada anggota DPRD, selanjtnya pada APBD calon penerima hibah tidak dilibatkan langsung.

\section{Akuntabilitas Hukum dan Kejujuran}

Pelaksanaan pemberian hibah daerah dalam pelaksanaan pemilihan Gubernur dan Wakil Gubernur Bali telah sesuai dengan peraturan yang ada. Pemberian hibah khususnya kepada Komisi Pemilihan Umum telah mengacu pada Peraturan Menteri Dalam Negeri No 32 tahun 2011 tentang hibah dan perubahan ketiga tentang Pedoman Pemberian Hibah dan Bantuan Sosial yang bersumber dari APBD dalam Peraturan Menteri Dalam Negeri Nomor 13 Tahun 2018. Pada pasal 1 dijelaskan bahwa Hibah adalah pemberian uang/barang atau jasa dari pemerintah daerah kepada pemerinta atau pemerintah daerah lainnya, perusahaan daerah, masyarakat dan organisasi kemasyarakatan. Maka dalam pemberian hibah daerah berupa uang kepada KPU Provinsi Bali menjadi sesuatu yang sah karena KPU merupakan perwakilan dari pemerintah pusat yang bertugas dalam menyelenggarakan pemilihan umum di tingkat daerah. Hal tersebut juga diperkuat pada pasal 6 bahwa hibah kepada pemerintah dapat diberikan kepada satuan kerja dari kementerian atau lembaga pemerintah non kementerian yang wilayahnya kerjanya berada dalam daerah yang bersangkutan.

Terkait dalam proses penganggaran maka proposal haru harus ditujukan kepada Gubernur atau kepala daerah. Setelah itu kepala daerah menunjukkan OPD terkait untuk melakukan evaluasi usulan. Terkait pengajuan hibah daerah dari KPU kepada Pemprov Bali menurut hasil wawancara yang ditunjuk sebagai leading sector adalah KesbangPol Bali. Nantinya KesbangPOL Provinsi Bali melaukan verifikasi kelayakan proposal tersebut dari segi perencanaan dan pembiayaan yang dibutuhkan. Setelah itu OPD terkait menyampaikan hasil evaluasi berupa rekomendasi kepada Kepala Daerah yakni Gubernur Bali. Tentu ada proses pembahasan dengan TAPD yang diketuai oleh sekretaris daerah Provinsi Bali. Rekomendasi Kepala KesbangPol dan pertimbangan TAPD menjadi dasar pencantuman alokasi anggaran hibah daerah dalam rancangan KUA (Kebijakan Umum Anggaran) dan PPAS (Prioritas Plafon Anggaran Sementara) hal tersebut diatur dalam pasal 9. Hibah daerah berupa uang yang diberikan kepada 
KPU dicantumkan dalam RKA-PPKD (Rencana Kerja dan Anggaran. Hal tersebut menjadi acuan dalam pembahasan anggaran di tingkat legislative yaitu DPRD Provinsi Bali. Proses yang telah dilakukan dalam pemberian hibah kepada KPU dalam pelaksanaan pemilihan Gubernur dan Wakil Gubernur telah sesuai dengan aturan yang ada serta tidak ada potensi atau indikasi penyimpangan.

\section{Akuntabilitas Proses.}

Proses awal dalam hibah daerah ini adalah, KPU Bali membuat Proposal (Perencanaan Anggaran) untuk Pemilihan Gubernur Bali berdasarkan Permedagri no. 32 tahun 2011 yng diubah dengan Permendagri No. 13 tahun 2018. Selanjutnya bersama OPD terkait melakukan verifikasi dan diskusi sehingga terjadi kesepakatan antara KPU dengan Pemerintah Daerah Bali mengenai jumlah anggaran ntuk Pilgub Rp. 229.336 000.000,00. Kesepakatan jumlah anggaran dengan mempertimbangkan proses yang telah berlangsung selama ini (dilihat perbandingannya). Pada saat pelaksanaan antinya, Pemberian dana dalam bentuk hibah. Pencairan dana disepakati melaui tiga tahapan yang mengacu pada Keputusan Gubernur Bali. Setelah melewati dua tahapan, tahap I Rp. 100.000.000.000,00, tahap II Rp. 25.000.000.000,00 DPRD mempermasalahkan proses penganggaran Pemilihan Gubernur Bali. Dengan dasar pertimbangan hasil studi banding ke Jawa Barat dan Lombok (NTB). Hasil audiensi dengan DPRD menyimpilkan dilakukan pengurangan anggran sejumlah Rp.155 milyard Walaupun telah diberikan penjelasan bahwa penganggran sesuai dengan Permendagri dan berdasarkan estimasi bahwa jumlah paslon 6 pasang dan jumlah calon pemilih.

Terjadinya pengurangan anggaran tidak menyurutkan langkah KPU untuk mensukseskan Pilgub Bali, KPU tetap bekerja. KPU mengurang pengeluaran sosialisasi, dana simulasi untuk panitya pelaksana pemilu, koordinasi (koordinasi dilakukan antar pimpinan-pimpinan saja, yang selanjutnya akan disampaikan ke daerah-daerah), dan biaya perjalanan ke daerah. Selain itu pencairan yang mendekati masa pemilihan berdampak pada masih ada dana tersisa akan dikembalikan. Hal ini dikarenakan tidak ada sisa dana pengeluaran pasca pemilihan gubernur dan wakil gubernur.

\section{Kajian Kebijakan: Akuntabilitas Hukum dan Kejujuran}

Pelaksanaan pemberian hibah daerah dalam pelaksanaan pemilihan Gubernur dan Wakil Gubernur Bali telah sesuai dengan peraturan yang ada. Pemberian hibah khususnya kepada Komisi Pemilihan Umum telah mengacu pada Peraturan Menteri Dalam Negeri No 32 tahun 2011 tentang hibah dan perubahan ketiga tentang Pedoman Pemberian Hibah dan Bantuan Sosial yang bersumber dari APBD dalam Peraturan Menteri Dalam Negeri Nomor 13 Tahun 2018. Pada pasal 1 dijelaskan bahwa Hibah adalah pemberian uang/barang atau jasa dari pemerintah daerah kepada pemerinta atau pemerintah daerah lainnya, perusahaan daerah, masyarakat dan organisasi kemasyarakatan. Maka dalam pemberian hibah daerah berupa uang kepada KPU Provinsi Bali menjadi sesuatu yang sah karena KPU merupakan perwakilan dari 
pemerintah pusat yang bertugas dalam menyelenggarakan pemilihan umum di tingkat daerah. Hal tersebut juga diperkuat pada pasal 6 bahwa hibah kepada pemerintah dapat diberikan kepada satuan kerja dari kementerian atau lembaga pemerintah non kementerian yang wilayahnya kerjanya berada dalam daerah yang bersangkutan.

Terkait dalam proses penganggaran maka proposal haru harus ditujukan kepada Gubernur atau kepala daerah. Setelah itu kepala daerah menunjukkan OPD terkait untuk melakukan evaluasi usulan. Terkait pengajuan hibah daerah dari KPU kepada Pemprov Bali menurut hasil wawancara yang ditunjuk sebagai leading sector adalah KesbangPol Bali. Nantinya KesbangPOL Provinsi Bali melaukan verifikasi kelayakan proposal tersebut dari segi perencanaan dan pembiayaan yang dibutuhkan. Setelah itu OPD terkait menyampaikan hasil evaluasi berupa rekomendasi kepada Kepala Daerah yakni Gubernur Bali. Tentu ada proses pembahasan dengan TAPD yang diketuai oleh sekretaris daerah Provinsi Bali. Rekomendasi Kepala KesbangPol dan pertimbangan TAPD menjadi dasar pencantuman alokasi anggaran hibah daerah dalam rancangan KUA (Kebijakan Umum Anggaran) dan PPAS (Prioritas Plafon Anggaran Sementara) hal tersebut diatur dalam pasal 9. Hibah daerah berupa uang yang diberikan kepada KPU dicantumkan dalam RKA-PPKD (Rencana Kerja dan Anggaran. Hal tersebut menjadi acuan dalam pembahasan anggaran di tingkat legislative yaitu DPRD Provinsi Bali. Proses yang telah dilakukan dalam pemberian hibah kepada KPU dalam pelaksanaan pemilihan Gubernur dan Wakil Gubernur telah sesuai dengan aturan yang ada serta tidak ada potensi atau indikasi penyimpangan.

\section{Kajian Kebijakan: Akuntabilitas Proses.}

Proses awal dalam hibah daerah ini adalah, KPU Bali membuat Proposal (Perencanaan Anggaran) untuk Pemilihan Gubernur Bali berdasarkan Permedagri no. 32 tahun 2011 yng diubah dengan Permendagri No. 13 tahun 2018. Selanjutnya bersama OPD terkait melakukan verifikasi dan diskusi sehingga terjadi kesepakatan antara KPU dengan Pemerintah Daerah Bali mengenai jumlah anggaran ntuk Pilgub Rp. 229.336 000.000,00. Kesepakatan jumlah anggaran dengan mempertimbangkan proses yang telah berlangsung selama ini (dilihat perbandingannya). Pada saat pelaksanaan antinya, Pemberian dana dalam bentuk hibah. Pencairan dana disepakati melaui tiga tahapan yang mengacu pada Keputusan Gubernur Bali. Setelah melewati dua tahapan, tahap I Rp. 100.000.000.000,00, tahap II Rp. 25.000.000.000,00 DPRD mempermasalahkan proses penganggaran pilgub Bali. Dengan dasar pertimbangan hasil studi banding ke Jawa Barat dan Lombok (NTB). Hasil audiensi dengan DPRD menyimpilkan dilakukan pengurangan anggran sejumlah Rp.155 milyard Walaupun telah diberikan penjelasan bahwa penganggran sesuai dengan Permendagri dan berdasarkan estimasi bahwa jumlah paslon 6 pasang dan jumlah calon pemilih.

Terjadinya pengurangan anggaran tidak menyurutkan langkah KPU untuk mensukseskan Pilgub Bali, KPU tetap bekerja. KPU mengurang pengeluaran sosialisasi, dana simulasi untuk panitya pelaksana pemilu, koordinasi (koordinasi dilakukan antar pimpinan-pimpinan saja, yang selanjutnya akan disampaikan ke daerah-daerah), dan biaya perjalanan ke daerah. Selain itu pencairan yang mendekati 
masa pemilihan berdampak pada masih ada dana tersisa akan dikembalikan. Hal ini dikarenakan tidak ada sisa dana pengeluaran pasca pemilihan gubernur dan wakil gubernur.

\section{Kajian Kebijakan: Akuntabilitas program}

Akuntabilitas Program merupakan suatu ukuran yang menunjukkan apakah suatu aktifitas organisiasi birokrasi atau lembaga publik atau pelayanan yang dilakukan oleh pemerintah sudah sesuai dengan norma dan nilai yang dianut oleh rakyat terhadap program yang menjadi ukuran standart penilaian serta apakah mampu mengakomodasikan kebutuhan rakyat terhadap lembaga tersebut, dengan demikian akutabilitas program terkait dengan falsafat bahwa lembaga eksekutif pemerintah atau lembaga pemilu harus bertanggung jawab secara langsung atau tidak langsung terhadap program yang direncanakan. Atau juga menurut Starling (1998:164) menyatakan bahwa akuntabilitas program merupakan kesediaan lembaga untuk menjawab kepada rakyat program yang telah di canangkan untuk kesuksesan suatu proses dalam menjawab pertanyaan publik.

Akuntabilitas program juga berarti bahwa program program organisasi/lembaga hendaknya merupakan program yang bermutu dan mendukung strategi dalam pencapaian visi, misi dan tujuan organisasi. Lembaga publik harus mempertanggungjawabkan program yang telah dibuat sampai pada pelaksanaan program.

Hasil observasi dan wawancara dari Tim Peneliti terhadap proses pengelolaan anggaran KPU tahun 2018 di Provinsi Bali mulai dari mekanisme perencanaan dan penetapan besar kecilnya alokasi anggaran telah memenuhi mekanisme prosedur yang telah diteptapkan sesuai dengan usulan Proposal KPUD kepada pemerintah dimana pemerintah mengalokkasi dana pemilu tidak menyimpang dari mekanisme prosedur dan sistem pendanaan dengan peraturan KPU. Komisi Pemilihan Umum Provinsi Bali dalam proses pembahasan kebutuhan tersebut dilakukan sebanyak 3 (tiga) kali (lihat tabel 1)

Tabel 1. Teknis penggaran dengan Pemerintah Provinsi Bali

\begin{tabular}{|l|l|}
\hline \multicolumn{1}{|c|}{ Kegiatan } & \multicolumn{1}{|c|}{ Keterangan } \\
\hline $\begin{array}{l}\text { Pembahasan Pertama } \\
\text { 17 Maret 2016 }\end{array}$ & $\begin{array}{l}\text { Pada proposal awal rencana kebutuhan anggaran dalam } \\
\text { pelaksanaan pemilihan Gubernur dan Wakil Gubernur } \\
\text { Tahun 2018 disampaikan dengan usulan sebesar } \\
\text { Rp. 268.635.895.529,- }\end{array}$ \\
\hline Pembahasan kedua & $\begin{array}{l}\text { Pembahasan kedua ini, pihak Komisi Pemilihan Umum } \\
\text { melakukan perubahan kebutuhan anggaran menjadi Rp. }\end{array}$ \\
& $\begin{array}{l}\text { 254.379.000.000,- terkait perubahan regulasi } \\
\text { penyelenggaraan pemilihan. Hal tersebut telah terverifikasi } \\
\text { oleh OPD terkait yang KesbangPol Prov Bali, maka }\end{array}$ \\
\hline
\end{tabular}




\begin{tabular}{|l|l|}
\hline & $\begin{array}{l}\text { selanjutnya disampaikan kepada tim TAPD yang dipimpin } \\
\text { oleh Sekretraris Daerah Provinsi Bali selaku ketua. }\end{array}$ \\
\hline Pembahasan ketiga & $\begin{array}{l}\text { Setelah melakukan diskusi dengan TAPD maka disepakati } \\
\text { pengurangan kegiatan sehingga terjadi perubahan anggaran } \\
\text { yang sebelumnya sebesar Rp. 254.379.000.000 menjadi Rp. } \\
229.360 .000 .000 . \text { Pengurangan tersebut tentunya didasari } \\
\text { oleh banyak pertimbangan dari kedua belah pihak. Maka } \\
\text { pada tanggal 17 Mei 2017 disepakati melalui NPHD dengan } \\
\text { tiga termin pembayaran. }\end{array}$ \\
\hline
\end{tabular}

Sumber: data sekunder

Berdasarkan data diatas dapat dijelaskan bahwa proses di tingkat eksekutif telah disetujui. Hal tersebut didasarkan oleh munculnya NPHD yang telah dikeluarkan dan ditanda tangani oleh Gubernur Bali. Kondisi tersebut juga diperkuat oleh pernyataan bagian keuangan BPKAD Provinsi Bali yang menegaskan bahwa komitmen dan kewajiban bagi daerah untuk melaksanakan Pilkada serentak adalah hal yang mutlak. Oleh karena itu Gubernur telah sepakat dengan NPHD di awal, sehingga proses legislative menjadi proses yang harus dilalui dan dihormati dalam politik anggaran (Wawancara, 7 september 2018).

Tahapan yang menjadi tahapan penting atau krusial dalam analisa penelitian ini adalah pada lembaga legislative di tingkat Provinsi Bali. Pada proses pembahasan dan setelah di bahas dalam sidang pleno DPRD atas inisiatif Dewan dengan berbagai pertimbangan maka dewan memutuskan dengan suatu perubahan anggaran. Perubahan tersebut menimbulkan polemik yaitu sampai pada taraf pembahasan mengalami penolakan dari KPU Provinsi Bali dengan pertimbagan jumlah pasangan dan kebutuhan pemilu serta segala alat kelengpakan pemilu dan program KPU melalui sosialisasi, pelatihan petugas KPPS, pemantau pemilu dimana apabila terjadi pemotongan anggaran maka program KPU akan mengalami kendala dan akan berdampak pada proses dan pelaksanaan pemilukada tahun 2018 dinilai tidak memadai sesuai dengan usulan awal KPU.

Terkait pelaksanaan Program Penguatan Kelembagaan Demokrasi dan Perbaikan Proses Politik di lembaga KPU Provinsi Bali diharapkan dari jumlah anggaran kurang lebih sebesar Rp. 229 milyard usulan KPU bersama pemerintah. Akan tetapi dengan berbagai pertimbangan terjadi pengurangan atau rasionalisasi oleh DPRD Provinsi Bali menjadi kurang lebih Rp 155 Milyard. Pertimbangan yang dimaksud dipertegas dan diperjelas berdasarkan hasil wawancara bahwa DPRD provinsi Bali memakai standar berdasarkan studi banding dibeberapa daerah atau melihat realisasi kegiatan nantinya (wawancara di BPKAD, 7 september 2018). Sedangkan perspektif KPU dalam menyusun anggaran adalah lebih fokus pada perencanaan anggaran karena kemungkinan besar muncul 6 (enam) calon, dimana 3 (tiga) dari partai politik dan 3 (tiga) dari calon perseorangan. Selain itu potensi terhadap munculnya sengketa atau gugutan dalam pilkada maka sangat dipertimbangkan dalam menyusun anggaran 
(wawancara sekretaris KPU, 7 september 2018). Maka hal tersebut justru menimbulkan kontradiktif dalam berpikir karena perencanaan dengan realisasi adalah sesuatu rangkaian yang tidak bisa dipisahkan.

Polemik tersebut tentunya menjadi sebuah tantangan, khususnya kepada KPU Provinsi Bali dalam melaksanakan pemilihan Gubernur dan Wakil Gubernur Bali 2018. Hal tersebut juga menjadi sebuah perhatian besar bagi Gubernur Bali saat itu, maka sebagai bentuk komitmen beliau dan pemrintah Provinsi Bali memberikan tambahan dana sekitar Rp. 30 Milyard kepada KPU untuk memperkuat kinerjanya (Wawancara BPKAD, 6 september 2018). Pihak KPU Provinsi Bali dalam menanggapi hal tersebut maka diperlukan efisiensi program karena keterbatasan anggaran. Hal tersebut tersirat dalam wawancara, bahwa KPU tetap bekerja untuk menghasilkan kinerja yang baik dalam pelaksanaan pemilihan Gubernur dan Wakil Gubernur Bali Tahun 2018. Anggaran yang digunakan dalam data pemilih sementara hingga data pemilih tetap hingga proses sosialisasi dan sebagainya menggunakan anggaran Rp. 155 Milyard tersebut. Sedangkan sisanya, yaitu sekitar Rp. 30 Milyard turun pada tanggal 22 Juni 2018 pada saat lima hari sebelum pencoblosan. Sehingga anggaran sisa tersebut banyak yang tidak terserap karena proses sebelum pemilihan KPU telah melakukan efisiensi.

Kondisi tersebut menyiratkan bahwa dinamisasi dalam politik anggaran tidak bisa kita hindari atau kita tebak kemana arah tujuannya. Akan tetapi, harus dihormati karena itu merupakan proses demokrasi dalam lingkung tata kelola pemerintahan. Jika dikaitkan dalam kajian teoritik khususnya perencanaan anggaran, maka dapat dikatakan proses tersebut belum mencermikan prinsip value for money dengan menerapkan money follows function. Peristiwa tersebut menggambarkan bahwa kegiatan pemilihan Gubernur dan Wakil Gubernur Bali 2018 yang dilakukan oleh KPU Bali lebih kepada functions follows money.

\section{Akuntabilitas kebijakan}

Komisi Pemilihan Umum Provinsi Bali harus mampu mempertanggungjawabkan kebijakan yang telah dirumuskan dan ditetapkan dengan melihat tujuan kebijakan dalam keterkaitan dampak kebijakan dimasa yang akan datang. Tujuan kebijakan harus secara jelas dan konkret terkait pihak pelaksana, sasaran dan dampak yang diharapkan dari kebijakan tersebut. Maka akuntabilitas kebijakan pada KPU provinsi Bali adalah kebijakan penyusunan anggaran.

Akuntabilitas yang paling utama pengukurannya adalah akuntabilitas kebijakan penyusunan anggaran KPU dalam setiap tahun berjalan, tugas utama para bendahara paling berisi dalam ketelitian membuat laporan pertanggungjawaban keuangan. Pengelolaan dana hibah pilkada selalu menjadi problem ditingkat pengembalian keputusan menjadi sesuatu yang paling beresiko, karena anggaran berada dalam kendali satuan kerja yang melaksanakan pemilihan. Ini adalah tanggungjawab yang berat, harus menjadi perhatian serius bagi pengambilan keputusan menyangkut akuntabilitas keuangan KPU Provinsi. Pada setiap rapat Penyusunan Laporan Pertanggungjawaban Bendahara BPP dan, sekretaris, bendahara dan PPK KPU 
Provinsi/kabupaten/kota se-Bali. Dalam membahas laporan pertanggungjawaban ini, para peserta didampingi oleh BPKP dan bagian keuangan KPU RI.

Indikator kedua dalam hal akuntabilitas kebijakan ini adalah laporan pertanggung-jawaban pengelolaan keuangan. Faktor penting yang harus diperhatikan pada pertanggung-jawaban keuangan dari KPU Provinsi Bali adalah bentuk laporan yang benar-benar mengakomodasi pertanggung-jawaban dan realisasi anggaran rutin tahunan yang dikelola oleh KPU Provinsi Bali selama proses pelaksanaan pemilukada. KPU Provinsi Bali selama tahun anggaran berjalan telah melengkapi laporan realisasi anggaran yang penyusunannya didasarkan pada neraca laporan keuangan. Meninjau sistem pelaporan keuangan yang ditetapkan KPU Provinsi Bali terdapat beberapa komitmen antara lain :

a. Terdapatnya komitmen atas perlindungan atas aset Pemerintah Provinsi Bali beserta instansi-instansinya. Pada perlindungan ini terdapat pencatatan, pemrosesan, serta pelaporan transaksi keuangan yang mengacu pada pelaporan keuangan yang sudah distandarkan.

b. Sistem pemberian informasi yang berimbang dan pelaksanaan kegiatan yang mengacu pada tupoksi disertai kepatuhan pada anggaran dengan mengacu pada aspek-aspek akuntabilitas. Pemberian nformasi keuangan secara transparan dan memberikan bahan dasar bagi perencanaan, pengelolaan, dan pengendalian kegiatan.

Salah satu aspek penting yang sudah diperhatikan dalam penyusunan laporan keuangan oleh KPU Provinsi Bali adalah pemberian informasi yang berimbang. Komitmen akuntabilitas dan transparansi pengelolaan keuangan negara ditunjukan dengan pemberian informasi kepada pihak manajemen dalam pengambilan keputusan yang mengarah pada perwujudan tata kelola pemerintahan yang baik (good governance).

Hal yang perlu digaris bawahi bahwa terdapat kesepahaman antara KPU Provinsi Bali dan Pemerintah dalam hal ini DPRD dan Pemerintah Provinsi Bali baik dalam prioritas besaran mata anggaran maupun peruntukan-nya. Selain melihat aspek efisiensi hal ini juga meningkatkan efektifitas kinerja yang dilakukan oleh KPU Provinsi Bali sebagai pihak pelaksana penyelenggara pemilu. Prinsip kehati-hatian dalam penyusunan anggaran semata mata adalah sikap kepatuhan yang berusaha diwujudkan oleh pihak pelaksana sesuai standar penganggaran kepemiluan yang sudah ditetapkan.

\section{SIMPULAN}

Berdasarkan hasil analisa yang dilakukan maka dapat disimpulkan beberapa hal. Pertama, perubahan dalam realisasi anggaran kepada KPU untuk pelaksanaan pemilihan Gubernur dan Wakil Gubernur didasarkan oleh pertimbangan DPRD Provinsi Bali. Pertimbangan tersebut lebih kepada hasil studi banding dibeberapa daerah dari realisasi anggaran dalam pelaksanaan pemilu. Selain itu, DPRD lebih melihat pada indeks biaya pemilih. Walaupun masih menjadi perdebatan nantinya karena butuh kajian akademis. 
Akuntabilitas secara hukum, proses, perencanaan telah sesuai dengan peraturan yang berlaku sehingga tidak ada potensi penyimpangan. Akan tetapi dari segi aspek akuntabilitas kebijakan secara efisiensi dalam mencapai tujuan tercapai sedangkan efektivitas kebijakan atau program yang dilakukan KPU tidak berjalan maksimal karena terjadi peningkatan jumlah suara tidak sah.

Berdasarkan permasalahan yang dihadapi maka kedepannya perlu strategi atau metode, yaitu Penanganan pilgub sebaiknya menjadi tanggung jawab KPU Pusat, KPU daerah hanya bertidak sebagai pelaksana. Hal ini disebabkan karena kemampuan ekonomi masing-masing daerah cenderung beragam atau dinami. Sehingga untuk menopang pembiayaan secara penuh dikhawatirkan menjadi beban berat bagi daerah. Selanjutnya, komitmen pemerintah daerah harus seiring dan sejalan antara eksekutif dan legislative dalam perencanaan anggaran. Politik anggaran jangan sampai hanya berorientasi pada kepentingan tertentu tetapi lebih kepada kepentingan publik.

Oleh karena itu perlu beberapa rekomendasi kebijakan yang sekira ideal dalam pelaksanaan demokrasi bukan menjadi beban atau menimbulkan konflik di daerah. Adapun rekomendasi yang revelan dalam penelitian guna mengatasi potensi keterbatasan anggaran adalah perlu dilakukan kajian ilmiah dalam pembiayaan dalam pemilu sehingga semua pihak memahami proses perencanaan, pelaksanaan dan pertanggungjawaban dalam pemilihan umum khususnya Gubernur dan Wakil Gubernur di Provinsi Bali. Selian itu, diperlukan adanya penguatan aturan dalam pemilu daerah terutama pelaksanaan pemilukada serentak dimana kontribusi pemerintah pusat dan pemerintah daerah seimbang. Misalnya terjadi kekurangan anggaran dari daerah maka pemerintah pusat melalui kementrian terkait memberikan bantuan finansial atau bantuan lainnya.

\section{REFERENSI}

Adisasmita, Raharjo, 2011. Manajemen pemerintah daerah, Graha ilmu Carino, Ledivina V, 1991. Organizatinal Behavior. Eight Edition Irwan/McGraw, Hill. New York. United Stated of America.

Ellwood, sheila. (1993). Parish and town Councils: Financial Accountability and management, Local Government Studies Vol. 19, pp. 368-386. Dalam Mardiasmo, 2002,2004,2009, Akuntansi sektor publik, Andi yogyakarta.

Ghartey. JB. (1987). Crisis, Accountability and Development in the Third World. London: Avebury. Dalam adisasmita, Raharjo, 2011. Manajemen pemerintah daerah, Graha ilmu

Hadjon. Philipus M. (1998). Tentang Wewenang Pemerintahan (Bestuurbevoegdheid), Pro Justitia Tahun XVI Nomor I Januari

Hasibuan, Malayu. (2016). Manajemen Dasar, Pengertian dan Masalah. Bumi Aksara. Jakarta.

Indroharto. (1989). Usaha Memahami Undang Undang Tentang. "Tata Usaha Negara." Sinar Harapan, Jakarta 
Ken Coghil. (2000). 'Best Practice in Accountability', (Paper presented at Pnvansatlon and Good Governance Conference, Parliament House, Melbourne., in Hodge,graeme,2004 "Accountability in the Privatised State:The changing of the guardians" Alternative Law Journal 4.

Ledivina. V. Carino.(1991). Organizatinal Behavior. Eight Edition Irwan/McGraw, Hill. New York. United Stated of America, 2002

Mardiasmo, 2002,2004,2009, Akuntansi sektor publik, Andi yogyakarta.

Riyadi dan Bratakusumah, Deddy. 2004. Perencanaan Pembangunan Daerah: Strategi Menggali Potensi dalam Mewujudkan Otonomi Daerah. Gramedia

Saidi, djafar,M, (2014). Hukum Keuangan Negara, cetakan keempat, Rajagrafindo persada, jakarta.

Sugiyono, (2016). Cara mudah menyusun Skripsi, Tesis, dan disertasi, Bandung; Alfabeta. 